Annals of Warsaw University of Life Sciences - SGGW

Land Reclamation No 49 (3), 2017: 153-166

(Ann. Warsaw Univ. of Life Sci. - SGGW, Land Reclam. 49 (3), 2017)

\title{
Hydrological and hydraulic analysis of a small lowland watercourse flow capacity and its functioning in the region of Silesian Lowlands in the context of rainfall water management
}

\author{
MIROSŁAW WIATKOWSKI, ŁUKASZ GRUSS \\ Institute of Environmental Engineering, Wrocław University of Environmental and Life Sciences
}

\begin{abstract}
Hydrological and hydraulic analysis of a small lowland watercourse flow capacity and its functioning in the region of Silesian Lowlands in the context of rainfall water management. The built-up areas in the catchments of small lowland watercourses faced with the risk of particularly devastating natural hazards. This risk is especially prevalent in the mouth reaches. The increasingly intense extreme natural phenomena, such as violent floods and long lasting droughts, increase the importance of irrigation, drainage and hydraulic structures. This paper presents the results of a comprehensive hydrological and hydraulic analysis of the functioning of a small lowland watercourse flow capacity in the context of water management in its catchment. The case study discussed below is a proposal that could be used by both the specialists and the designers working in the field of water management. Methods are proposed for the determination of heavy rainfall in small ungauged agricultural catchments for the purpose of rainfall water management. The area under study consists of the lower reaches of R-4, a watercourse located in the agricultural village of Dobrzeń Wielki in the Opolskie province, the Upper Odra river basin. The authors have assessed the flow capacity of R-4 based on EN 752:2008 and carried out hydrological calculations for the area being analysed as well as hydraulic calculations for R-4. It was concluded, that the small lowland watercourse and the communication structures (culverts and pipelines) on its way indicated low flow capacity. Consequently, a rainfall water management concept was proposed for the water flowing in the watercourse. A small retention reservoir with a total capacity of $3,132 \mathrm{~m}^{3}$ and a surface area of $2,088 \mathrm{~m}^{2}$ was also proposed to be constructed. In order to calculate the water
\end{abstract}

inflow to the reservoir the Bogdanowicz and Stachy formula was used. This model was selected because the maximum rainfall on agricultural land calculated from this formula meets the requirements of EN 752:2008. Moreover, this formula produced the highest runoff values compared to other models. The research carried out is in line with the goals of water management in rural areas, where the management model has changed.

Key words: small lowland watercourse, ungauged catchment, rainfall intensity, flood, precipitation model, small retention, reservoir

\section{INTRODUCTION}

The changes in the usage of land, the rise in the density of population and buildings and the climate change result in a space- and time-related change in the nature of river runoff (Banasik and Hejduk 2012). The densely populated areas in the mouth reaches of rivers on lowlands, which are hubs of agricultural production, are particularly vulnerable to the devastating effects of natural hazards. The small slopes of terrain characteristic for lowland catchments increase the susceptibility to flooding on considerable areas (Brauer et al. 2014). Over the last 20 years, the extreme natural phenomena of increasing intensity, such as the heavy or long lasting rainfall lead to 
considerable economic losses (Kotowski et al. 2010). The risk and hazard related to extreme weather condition events result both from the probability of their occurrence for a given region and from the negative effects on the environment, society and agriculture (Łabędzki 2006, Kuchar et al. 2014). The principles of dimensioning of soil drainage systems, including the principles of dimensioning of drainage, irrigation and sewer systems should be improved (Przybyła et al. 2011a, Brauer et al. 2014).

In view of the increasingly violent abnormal weather conditions and increasingly frequent extreme phenomena (violent floods or long lasting droughts) the role and importance of irrigation and drainage structures is bound to increase in the coming years (Marcilonek et al. 1995, Nyc and Pokładek 2007, Rutkowski et al. 2011). Unused opportunities for small retention in rural areas are identified as dangers in flood and drought prevention (Mrozik and Przybyła 2013). According to Przybyła et al. (2011b), the upkeep of irrigation and drainage structures and systems consists in maintenance, repairs and possibly restoration to keep them operational as required. Appropriate maintenance allows the usage of structures in decent technical condition for as long as possible and prevents them from deteriorating too fast. Mosiej et al. (2011) indicates, that on the one hand there is a number of contemporary conditions which limit the improvement of poor water infrastructure, on the other hand there are conditions that force a positive change in this feature.

This paper aims to provide a hydrological and hydraulic analysis of the functioning of a small lowland wa- tercourse flow capacity denoted R-4 (Żydówka river tributary) in the village of Dobrzeń Wielki (south of Poland, the Opolskie province) in the Upper Odra river basin against the context of rainfall water management. The paper presents a methodology for the determination of heavy rainfall in small ungauged agricultural catchments for the purpose of rainfall water management.

\section{MATERIAL AND METHODS}

\section{Characterisation of the subject of research}

The catchment of the small lowland watercourse R-4 is located in the villages of Dobrzen Wielki and Brzezie in the Dobrzeń Wielki commune, Opolskie province, in the water region of Middle Odra (Fig. 1). The catchment of R-4 is ungauged. The catchment area of this watercourse is $0.829 \mathrm{~km}^{2}$. The catchment is visibly asymmetrical in shape and its southern part is more developed. Most of the catchment surface is covered with meadows and arable land $(84.3 \%)$, the second largest part - with forest $(1.2 \%)$ and the rest of the surface $(16.9 \%)$ is covered with the built-up areas. The lower part of the catchment is covered mostly with built-up areas.

The division of Poland into climate regions presented by Alojzy Woś (1999) locates the catchment of R-4 in the Southern Lower Silesian Region (R-XXV). Over the years 1951-1980 there were on the average 162 days with precipitation in the area under study (Woś 1999). However, this classification does not include the period of huge floods triggered by rainfall, which occurred in 


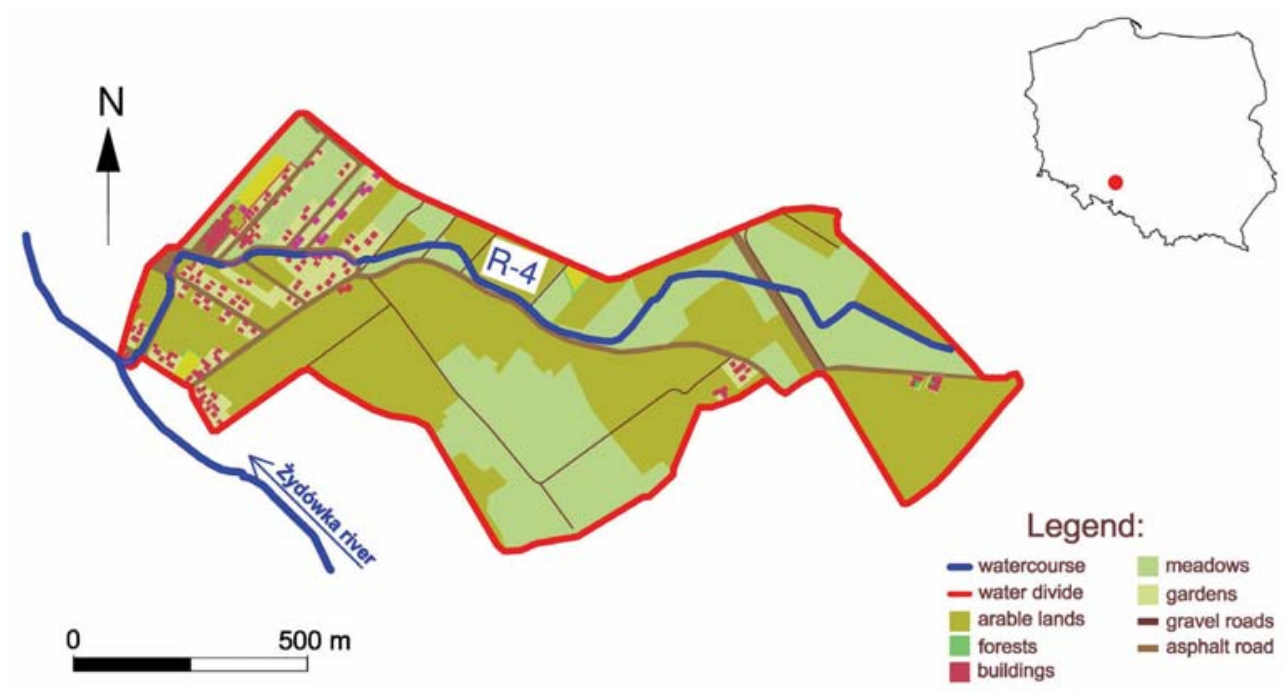

FIGURE 1. Catchment of the small lowland watercourse R-4

the Odra river basin area in 1854,1903 , 1997 and 2010.

The development of small villages means that land is required for residential housing and services and this in turn increases the overall area of paved surfaces. Consequently, the existing watercourses in the built-up area are being modernized. This is exemplified by the watercourse section providing drainage in Dobrzeń Wielki, which was modernized through the construction of communication structures (culverts and pipelines).

The watercourse is $2.15 \mathrm{~km}$ long and flows into the Żydówka river at $\mathrm{km} 12,642$ of its course. The area of the watercourse was developed by constructing nine road culverts and four pipelines under access drives to private properties and parking lots. Additionally, the biological reinforcement of banks was replaced with a technical reinforcement system - grid pavers. At km 0,000-0,400 both the bed and the embankments of R-4 are protect- ed with grid pavers. Above this section, the channel is protected only with turf. The bottom width of the watercourse is variable and ranges from 0.6 to $0.8 \mathrm{~m}$ at

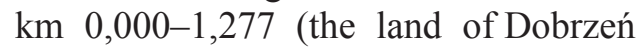
Wielki) and $0.9 \mathrm{~m}$ at $\mathrm{km} \mathrm{1,277-2,150}$ (the land within the local administrative unit of Brzezie). In the area under study heavy fen soils occur (mapa.opolskie.pl, Programme for Environmental Protection 2005).

\section{Scope of work}

The scope of work includes: determining the catchment area (the surface area of the drainage basin), analysing the structure of land use in the catchment, hydraulic field measurement of the watercourse and of the structures located on it, determining the flow capacity of the watercourse channel, calculating the discharge of the communication structures built on the watercourse, calculating the intensity of design storm with a given exceedance probability $(p \%)$ and a given 
duration time $(t)$, determining the runoff of precipitation from the catchment under study, selection and dimensioning of the small retention reservoir.

\section{Determination of the drainage basin area and of its structure of land use}

The surface area of the catchment was determined based on the topographic maps in a scale of 1:10000, in the "1992" coordinate system. We analysed the topographic profile presented in the numerical model of terrain available at http://mapa.opolskie.pl. Theoretical results were validated by field work. Moreover, the usage of the catchment of R-4 was determined and the surface runoff coefficient was calculated.

The flow capacity of the channel at 10 cross sections of R-4 was calculated from the low water level and the high water level of the communication structures
(Fig. 2). The total flow was determined using Manning's formula (EN 257:2008, Sobota 2003).

The discharge values for the communication structures (culverts and pipelines) were determined for entirely submerged (filled up) channels. The velocity coefficient $(C)$ was calculated from the Kutter relationship and the roughness coefficient $(m)$ was assumed to be the one for concrete pipes $(m=0.35)$.

In order to determine the characteristics of rainfall for the assumed duration times $(15,30,60$ and $120 \mathrm{~min})$, three precipitation models were used by Bogdanowicz and Stachy, Lambor, Wołoszyn (Ciepielowski and Dąbkowski 2006, Kotowski et al. 2010).

In order to determine the runoff of precipitation water from the catchment under study, the European standard EN 752:2008 was used. According to this standard, the recommended frequency of

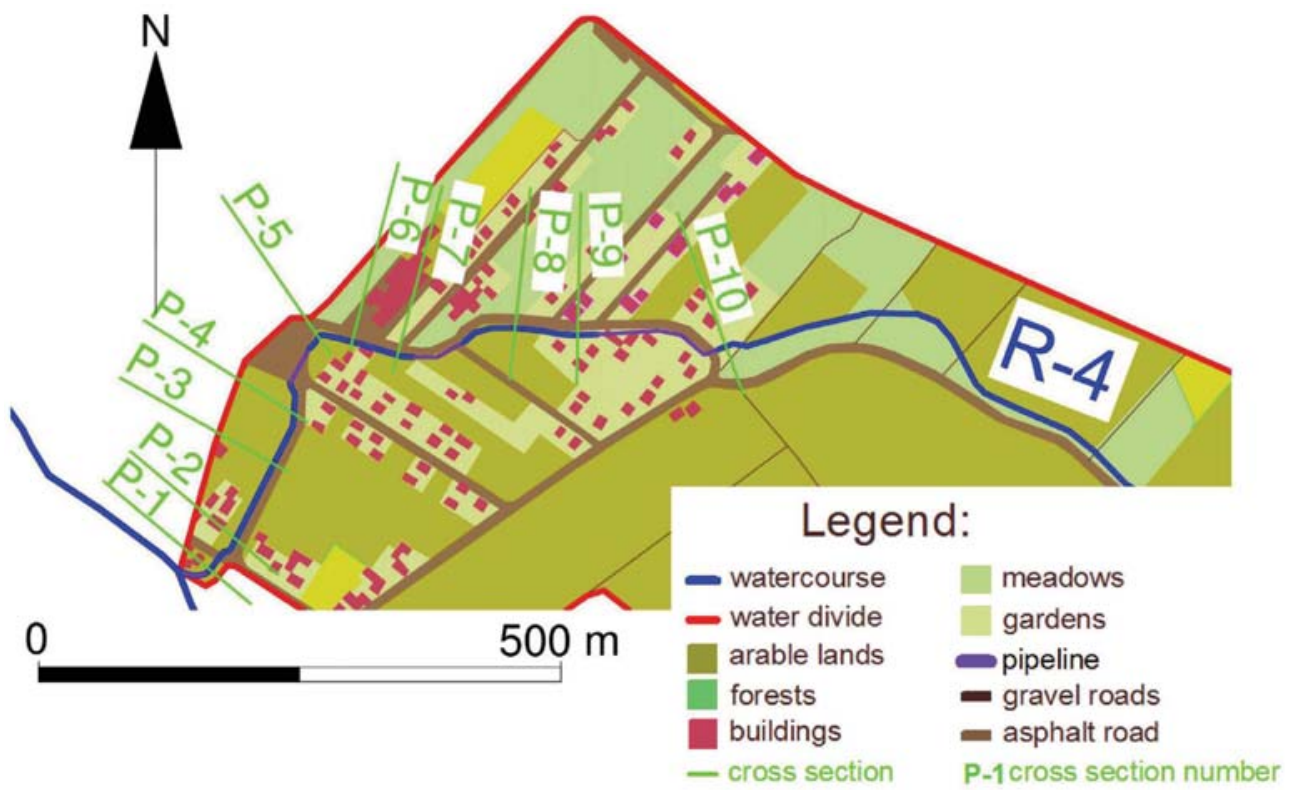

FIGURE 2. Location of cross sections on R-4 
design storm to be used in the design of systems intended for evacuation of rainwater in rural areas should be once every 10 years $(p=10 \%)$.

After calculation of the rainfall characteristics, the precipitation runoff of the analysed catchment $(Q)$ was determined according to the rational equation:

$Q=k C I A$

where:

$k$ - units conversion factor;

$C$-dimensionless runoff coefficient;

$I$ - rainfall intensity $\left(\mathrm{mm} \cdot \mathrm{min}^{-1}\right)$;

$A$ - area receiving rainfall $\left(\mathrm{km}^{2}\right)$.

A rainfall reservoir with restricted outflow capable of holding an appropriate amount of water was designed. The calculations for the designed reservoir were carried out according to the German standard ATV-A117 (1977) and in line with the guidelines presented by Geiger and Dreiseitl (1999) and Słyś (2008). In order to calculate the discharges, the highest calculated values of rainfall intensity for various rainfall duration times (four variants) were used. The highest value of flow allowed us to calculate the time of inflow of water to the reservoir. The depth and the slope of embankments were assumed in accordance with the design principles. When assuming the outflow from the reservoir, the lowest value of discharge for the channel and for the communication structure on the section "watercourse mouth - designed reservoir" was accounted for. This smallest value was assigned to be the value of outflow. It was assumed that this value would not cause damage downstream of the reservoir.

The time of inflow of water to the reservoir was determined as the ratio between the watercourse length on the section "reservoir dam - source" and the flow rate. From the relationship: time of inflow of water to the reservoir and the coefficient of flow reduction $(\eta)$ the dimensioning coefficient $\mathrm{Br}$ was read from the nomogram.

The capacity of the reservoir was determined as the product of reservoir's volume and the dimensioning coefficient $\mathrm{Br}$.

\section{RESULTS AND DISCUSSION}

Based on the analysis, it is clear that ground cover of the catchment under study is variable, hence a dimensionless runoff coefficient was determined: $C=0.14$.

The inventorying of structures located on small watercourse R-4 has showed that the mouth of R-4 where it enters the Żydówka river consists of a pipeline denoted r-I, which has the smallest diameter $(0.4 \mathrm{~m})$ of all the average diameter values of other communication structures. Also the diameters of the two structures located in the built-up area, i.e. the culvert $2 \mathrm{P}$ and the pipeline r-II with diameter of $0.45 \mathrm{~m}$, are smaller than the other diameters. The locations and parameters of structures are given in Table 1 (Wiatkowski et al. 2012).

The calculated values of the flow capacity of the small lowland watercourse R-4 upstream and downstream of the communication structures are presented in Table 2. The highest flow capacity was measured at the cross section P-7 $\left(2.768 \mathrm{~m}^{3} \cdot \mathrm{s}^{-1}\right)$ and the lowest value was recorded at $\mathrm{P}-10\left(0.513 \mathrm{~m}^{3} \cdot \mathrm{s}^{-1}\right)$.

The calculated discharge values for culverts and pipelines are given in Table 3. The smallest discharge in all the 
TABLE 1. Structures located on the watercourse R-4 within the village administrative units of Dobrzeń Wielki and Brzezie

\begin{tabular}{|c|c|c|c|c|}
\hline \multirow[b]{2}{*}{ Location } & \multirow[b]{2}{*}{ Type of structure } & \multirow[b]{2}{*}{$\begin{array}{l}\text { Structure number } \\
\text { and symbol }\end{array}$} & \multicolumn{2}{|c|}{ Parameters } \\
\hline & & & $\begin{array}{l}\text { diameter or cross } \\
\text { section dimen- } \\
\text { sions } \mathrm{h} \times \mathrm{b}(\mathrm{m}) \\
\end{array}$ & Length (m) \\
\hline \multicolumn{5}{|c|}{ District of Dobrzeń Wielki } \\
\hline $\mathrm{hm} 0.00-0.20$ & pipeline & $\mathrm{r}-\mathrm{I}$ & 0,4 & 20,0 \\
\hline hm 0.41 & culvert & $1 \mathrm{P}$ & $1,4 \times 1,0$ & 16,0 \\
\hline hm 1.49 & culvert & $2 \mathrm{P}$ & 0,45 & 4,0 \\
\hline $\mathrm{hm} 2.38-2.70$ & pipeline & r-II & 0,45 & 32,0 \\
\hline $\mathrm{hm} 2.84$ & culvert & $3 \mathrm{P}$ & 0,6 & 10,0 \\
\hline hm 3.35 & culvert & $4 \mathrm{P}$ & 0,6 & 4,0 \\
\hline $\mathrm{hm} 3.90-4.30$ & pipeline & r-III & 0,5 & 50,0 \\
\hline hm 5.31 & culvert & $5 \mathrm{P}$ & 0,5 & 4,0 \\
\hline $\mathrm{hm} 6.21-7.26$ & pipeline & r-IV & 0,5 & 105,0 \\
\hline $\mathrm{hm} 8.23$ & culvert & $6 \mathrm{P}$ & 0,5 & 25,0 \\
\hline $\mathrm{hm} 9.58$ & culvert & $7 \mathrm{P}$ & 0,6 & 4,0 \\
\hline \multicolumn{5}{|c|}{ District of Obręb Brzezie } \\
\hline $\mathrm{hm} 17.30$ & culvert & $8 \mathrm{P}$ & - & - \\
\hline hm 17.40 & culvert & $9 \mathrm{P}$ & 1,00 & 2,5 \\
\hline
\end{tabular}

TABLE 2. Flow capacity of R-4 calculated at 10 cross sections

\begin{tabular}{|c|c|c|}
\hline Cross section number & Watercourse $(\mathrm{km})$ & $\begin{array}{c}\text { Cross section discharge }- \\
Q\left(\mathrm{~m}^{3} \cdot \mathrm{s}^{-1}\right)\end{array}$ \\
\hline P-1 & 0.023 & 1.108 \\
\hline P-2 & 0.060 & 0.809 \\
\hline P-3 & 0.140 & 0.709 \\
\hline P-4 & 0.160 & 1.373 \\
\hline P-5 & 0.230 & 2.364 \\
\hline P-6 & 0.300 & 0.901 \\
\hline P-7 & 0.380 & 2.768 \\
\hline P-8 & 0.450 & 1.120 \\
\hline P-9 & 0.600 & 1.032 \\
\hline P-10 & 0.750 & 0.513 \\
\hline
\end{tabular}


TABLE 3. Discharge values of the communication structures in district of Dobrzeń Wielki

\begin{tabular}{|l|c|c|c|}
\hline Location & Type of structure & $\begin{array}{c}\text { Structure number and } \\
\text { symbol }\end{array}$ & Discharge $-\mathrm{Q}\left(\mathrm{m}^{3} \cdot \mathrm{s}^{-1}\right)$ \\
\hline $\mathrm{hm} 0.000-0.020$ & pipeline & $\mathrm{r}-\mathrm{I}$ & 0.071 \\
\hline $\mathrm{hm} 0.041$ & culvert & 1P & 1.717 \\
\hline $\mathrm{hm} 0.049$ & culvert & 2P & 0.098 \\
\hline $\mathrm{hm} 0.238-0.270$ & pipeline & $\mathrm{r}-\mathrm{II}$ & 0.098 \\
\hline $\mathrm{hm} 0.284$ & culvert & 3P & 0.215 \\
\hline $\mathrm{hm} 0.335$ & culvert & $4 \mathrm{P}$ & 0.215 \\
\hline $\mathrm{hm} 0.390-0.430$ & pipeline & $\mathrm{r}-\mathrm{III}$ & 0.131 \\
\hline $\mathrm{hm} 0.531$ & culvert & 5P & 0.131 \\
\hline $\mathrm{hm} 0.621-0.726$ & pipeline & $\mathrm{r}-\mathrm{IV}$ & 0.131 \\
\hline $\mathrm{hm} 0.823$ & culvert & $6 \mathrm{P}$ & 0.131 \\
\hline $\mathrm{hm} 0.958$ & culvert & $7 \mathrm{P}$ & 0.019 \\
\hline
\end{tabular}

surveying area of Dobrzeń Wielki is that of pipeline $\mathrm{r}-\mathrm{I}\left(0.071 \mathrm{~m}^{3} \cdot \mathrm{s}^{-1}\right)$ which constitutes the mouth of R-4, the highest value of discharge is that of culvert $1 \mathrm{P}$ $\left(1.717 \mathrm{~m}^{3} \cdot \mathrm{s}^{-1}\right)$.

The hydrological calculations of rainfall intensity which were carried out using three precipitation models allowed us to obtain the maximum catchment runoff value for the rainfall duration time of 15 , 30,60 and $120 \mathrm{~min}$ and the probability of occurrence of 2, 5, 10, 20, 50 and $100 \%$ (Fig. 3). The highest rainfall intensity with $p=1 \%$ and $D=15$ min was obtained using the Wołoszyn formula. For the duration time of 30,60 and $120 \mathrm{~min}$, the highest values were those obtained from the Bogdanowicz and Stachy formula. The results for the rainfall intensity with the probability of occurrence of 2,5 , 10,20 and $50 \%$ and the duration time of $15,30,60$ and $120 \mathrm{~min}$ indicate that the highest values are those obtained from the Bogdanowicz and Stachy formula. However, the highest rainfall intensity with $p=100 \%$ was obtained using the Lambor formula.
The hydrological calculations of rainfall intensity which were carried out using the three precipitation models allowed us to obtain the catchment runoff values for the rainfall duration time of $15,30,60$ and $120 \mathrm{~min}$ and the probability of occurrence of $1,2,5,10,10,20$ and $100 \%$.

In the analysis of flow capacity of R-4 and of its structures we used the values of runoff corresponding to $p=10 \%$ determined with the Bogdanowicz and Stachy formula, this is because these values are higher than those obtained from the Lambor and Wołoszyn formulae.

By comparing: (a) the values of inflow of water to the channel of R-4 obtained from the Bogdanowicz and Stachy formula for $p=10 \%$, and (b) the discharge of the channel of R-4, we established that for a rainfall lasting $120 \mathrm{~min}$ the channel is able to convey an inflow of $Q=0.600 \mathrm{~m}^{3} \cdot \mathrm{s}^{-1}$ of water over its entire length except for the cross section P-10. However, the shorter the rainfall duration time, the smaller the amount of surface runoff water that can be accommo- 

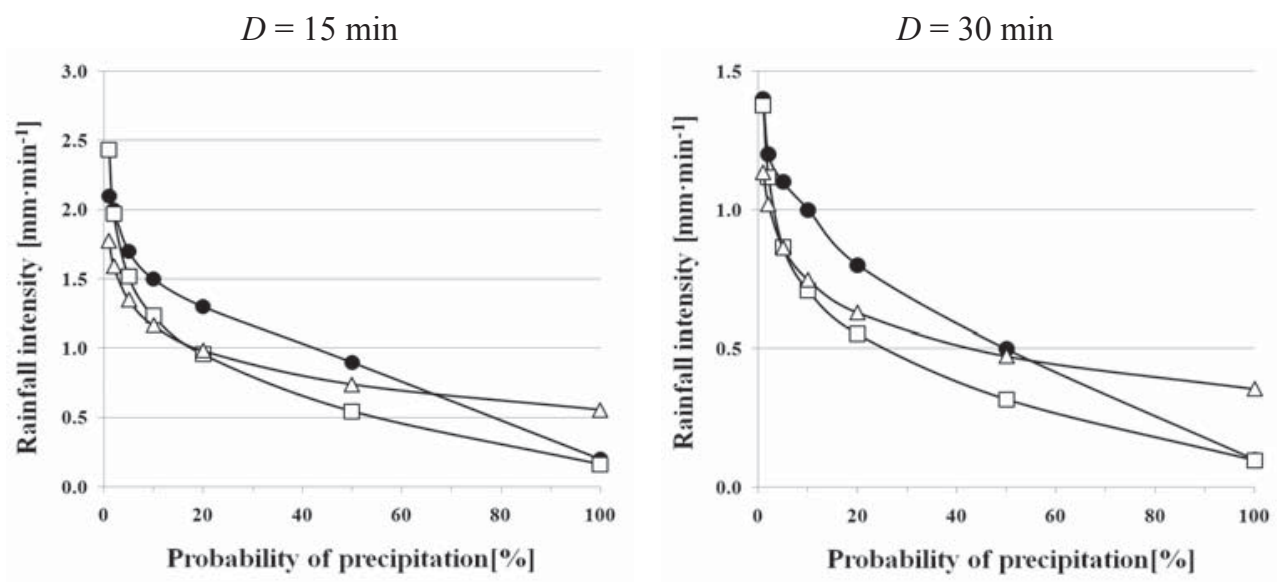

$D=60 \min$
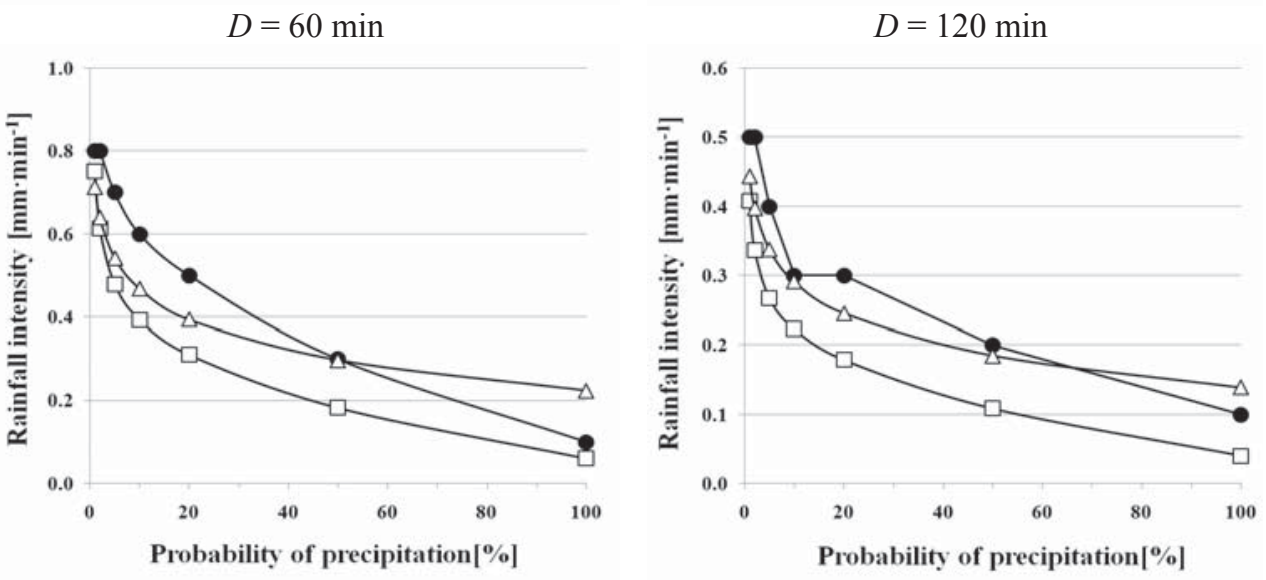

Bogdanowicz i Stachy

$\square$ Woloszyn $\quad \triangleleft$ Lambor

FIGURE 3. The curves of probability of maximum precipitation with the duration time $(D)$ of 15,30 , 60 and $120 \mathrm{~min}$, determined according to selected precipitation models

dated in the channel. When the rain lasts $60 \mathrm{~min}$ (and the inflow to the channel is $\left.Q=1.160 \mathrm{~m}^{3} \cdot \mathrm{s}^{-1}\right)$, the channel capacity is sufficient only on some sections of the watercourse: at hm 1.49-2.38 (the cross sections P-4 and P-5) and at hm 3.35-3.90 (cross section P-7). When the rain lasts 30 minutes (and the inflow to the channel is $Q=1.934 \mathrm{~m}^{3} \cdot \mathrm{s}^{-1}$ ), the channel capacity is sufficient only for cross sections $\mathrm{P}-5$ and $\mathrm{P}-7$. If the rainfall in the catchment lasted only $15 \mathrm{~min}$, the inflow value would be too high $\left(Q=2.900 \mathrm{~m}^{3} \cdot \mathrm{s}^{-1}\right)$ to be accommodated by the channel.

Similar to the rainfall determined from the Lambor formula with the duration time of $15 \mathrm{~min}$ and the probability of occurrence of 1 and $2 \%$, the intensity of rainfall with the duration time of $15 \mathrm{~min}$ and the probability of occurrence of $1,2,5 \%$ determined from the formulae of Bogdanowicz and Stachy and Wołoszyn would yield 
a runoff in excess of the channel discharge at the calculated cross sections. For the duration times under study (60, $120 \mathrm{~min})$, only the inflow of water to the channel with $p=100 \%$ is smaller than the discharge of the channel of R-4. channel of watercourse R-4 unchanged. The authors propose to construct a retention reservoir with the surface area of 2,088 $\mathrm{m}^{2}$, which could hold water during floods. Other parameters of the reservoir are given in Table 4.

TABLE 4. Dimensions of the retention reservoir being designed in four variants

\begin{tabular}{|l|c|c|c|c|}
\hline Variant number & 1 & 2 & 3 & 4 \\
\hline Rainfall duration time $-t(\mathrm{~min})$ & 15 & 30 & 60 & 120 \\
\hline Water inflow to the reservoir $-Q\left(\mathrm{~m}^{3} \cdot \mathrm{s}^{-1}\right)$ & 2.900 & 1.934 & 1.160 & 0.600 \\
\hline Coefficient of reduction $-\eta$ & 0.03 & 0.04 & 0.07 & 0.13 \\
\hline Inflow duration time $-t(\mathrm{~min})$ & 43 & 43 & 43 & 43 \\
\hline Dimensioning coefficient $-\mathrm{Br}(\mathrm{s})$ & 1,080 & 1,020 & 980 & 620 \\
\hline Volume of the reservoir $-V_{\text {wym }}\left(\mathrm{m}^{3}\right)$ & 3,132 & 1,972 & 1,137 & 360 \\
\hline Surface area of the reservoir $-F\left(\mathrm{~m}^{2}\right)$ & 2,088 & 1,315 & 758 & 240 \\
\hline
\end{tabular}

The calculations of discharge carried out for pipelines and culverts indicate that for a rainfall lasting 60 and $120 \mathrm{~min}$ and $p=10 \%$ calculated from all the three models only culvert $1 \mathrm{P}$ has a diameter sufficient to evacuate water. For rainfalls lasting 15, 30, 60 and $120 \mathrm{~min}$ and $p=10 \%$, the parameters (diameters) of all other structures are too small to evacuate water.

In order to calculate the parameters of the small retention reservoir, the runoff with $p=10 \%$ obtained from the Bogdanowicz and Stachy formula was used. The model was selected because the maximum rainfall on agricultural land calculated from this formula meets the requirements of EN 752:2008. Moreover, this formula produced the highest runoff values compared to other models.

The rainfall management concept developed by the authors would allow to keep the existing parameters of the
It was assumed that the reservoir would be $1.5 \mathrm{~m}$ deep and that the slope ratio of embankments would be $1: 2$. The calculated duration of water inflow to the reservoir would be $43 \mathrm{~min}$. The maximum inflow of water to the reservoir was assumed to be the values of inflow with $p=10 \%$ for various rainfall duration times. The outflow from the reservoir was assumed to be the value corresponding to $Q=0.071 \mathrm{~m}^{3} \cdot \mathrm{s}^{-1}$. Figure 4 shows the location of the reservoir.

The main goal of the proposed small reservoir is flood protection. As confirmed in the literature (Mioduszewski and Łoś 2002, Wiatkowski 2016), any reservoir, regardless of its type and size, contributes to curbing the flood risk, simply by accumulating the excess of rainfall or meltwater. When designing a reservoir, one must above all else account for the amount of water that will be stored in it and for the reservoir location. In the case under study it is possible 


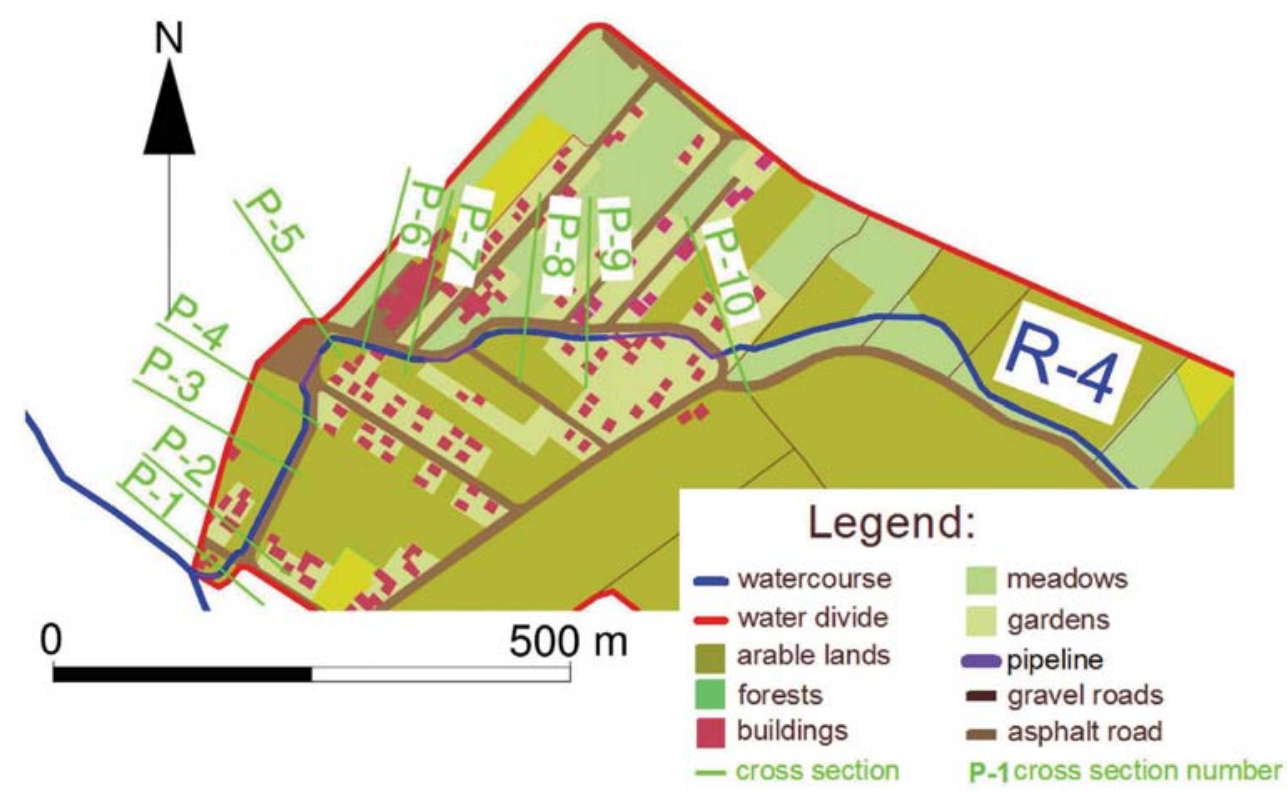

FIGURE 4. Location of the designed reservoir

to find a suitable location for a reservoir. It is also extremely important to remember that any reservoir is a technical structure and requires conscious exploitation, maintenance and repair (Wiatkowski 2015, Mioduszewski 2016).

\section{CONCLUSIONS}

Analyses prove that the watercourse R-4 will not be able to accommodate in its channel the inflow of water determined based on the Bogdanowicz and Stachy and Wołoszyn formulae with the following characteristics: rainfall duration time of $15 \mathrm{~min}$, probability of 1,2 , and $5 \%$. Neither will it be able to accommodate the inflow determined based on the Lambor formula with the rainfall duration time of $15 \mathrm{~min}$ and the probability of occurence of 1 and $2 \%$. For the du- ration times under study (60, $120 \mathrm{~min})$, only the inflow of water to the channel with $p=100 \%$ is smaller than the discharge of the channel of R-4.

The values of runoff obtained from the Bogdanowicz and Stachy formula, determined for $p=10 \%$ and compared to the channel discharge of R-4 show that the flow capacity of this channel is too small to accommodate the runoff resulting from a $15 \mathrm{~min}$ long rainfall. This may create a risk of floodings. Only for a rainfall lasting $120 \mathrm{~min}$ the runoff will be smaller than the discharge values determined for almost the entire length of the watercourse (except for cross section P-10).

The rainfall lasting 15 min with the probability of occurrence of 1,2 and $5 \%$ determined from the formulae of Bogdanowicz and Stachy and Wołoszyn, similarly to the $15 \mathrm{~min}$ rainfall deter- 
mined from the Lambor formula with the probability of 1 and $2 \%$ would produce a runoff exceeding the channel discharge at the calculated cross sections.

As proved by a field survey, there are several culverts and pipelines on the watercourse. The parameters of these structures (length and diameter) are varied. The calculated discharge values of the culvert and pipeline cross sections were compared with the obtained runoff values calculated for $p=10 \%$ (using all the three models). These values indicate that only the discharge of culvert $1 \mathrm{P}$ is high enough to evacuate water when the rainfall duration time is 60 and $120 \mathrm{~min}$. All other communication structures are too narrow (the diameters are too small). The precipitation resulting from a 15 or 30 min long rainfall will exceed the discharge of all the communication structures located on the watercourse. The fact that the discharges of the communication structures are so small increases the risk of flooding on the land adjacent to the watercourse. The watercourse R4 and its structures within the administrative area of Dobrzeń Wielki require a reconstruction. However, in some cases reconstruction may turn out to be unjustified either economically or socially. One might also consider construction of a reservoir.

In order to calculate heavy rainfall in agricultural areas according to $\mathrm{EN}$ $752: 2008$, it is recommended to use the Bogdanowicz and Stachy formula, since the maximum rainfall obtained from it is in line with the requirements of this standard. Moreover, this formula produced the highest runoff values compared to other models.
The initial concept of handling the rainfall water evacuated through R-4 water course in Dobrzeń Wielki is based on the construction of a small retention reservoir with a capacity of $3,132 \mathrm{~m}^{3}$ and a surface area of $2,088 \mathrm{~m}^{2}$. This reservoir should hold enough water during floods.

The methodology proposed in this paper for a hydrological and hydraulic analysis of the functioning of a small lowland watercourse R-4 flow capacity is an interesting concept that might be used in a practical way as a component of a reasonable water management.

The research carried out are consistent of the problem and consistent in line with the goals of water management in rural areas, where the management model has changed.

It should be noted that the upkeep of valley drainage and irrigation systems and the watercourses both as recipients of water from drainage structures and as channels allowing flood water evacuation in a manner safe for the inhabitants is paramount for a rational and efficient management of water resources as well as for safety.

\section{REFERENCES}

ATV-Regelwerk, Arbeitsblatt A 117. 1977: Richtlinien für die Bemesung, die Gestaltung und den Betrieb von Regenrückhalterbecken. St. Augustin.

BANASIK K., HEJDUK L. 2012: Long-term Changes in Runoff from a Small Agricultural Catchment. Soil \& Water Res. 7 (2), 64-72.

BRAUER C.C., TEULING A.J., TORFS P.J.J.F., UIJLENHOET R. 2014: The Wageningen Lowland Runoff Simulator (WALRUS): a lumped rainfall-runoff model for catchments with shallow 
groundwater. Geosci. Model Dev. 7, 2313-2332 Retrieved from www.geoscimodel-dev.net/7/2313/2014/ [accessed 26.04.2017].

CIEPIELOWSKI A., DĄBKOWSKI L. 2006: Metody obliczeń przepływów maksymalnych w małych zlewniach rzecznych [Methods for calculating maximum discharges in small catchments]. Wydawnictwo Projprzem-EKO Bydgoszcz [in Polish].

EN 752:2008. Drain and serwer systems outside buildings.

GEIGER W., DREISEITL H. 1999: Nowe sposoby odprowadzania wód deszczowych. [New methods of rainwater drainage]. Wydawnictwo Projprzem-EKO, Bydgoszcz [in Polish].

KOTOWSKI A., KAŹMIERCZAK B., DACEWICZA. 2010: Modelowanie opadów do wymiarowania kanalizacji [Precipitation modeling for sewerage measuring]. PAN, Komitet Inżynierii Lądowej i Wodnej Instytut Podstawowych Problemów Techniki. Studia z Zakresu Inżynierii 68. [Engl. summ.].

KUCHAR L., IWAŃSKI S., JELONEK L., SZALIŃSKA W. 2014: A modeling framework to assess the impact of climate change on river runoff. Meteorol. Hydrol. Water Manag. 2 (2), 49-63.

ŁABĘDZKI Ł. 2006: Susze i powodzie - zagrożenia dla rolnictwa. In: Woda w krajobrazie rolniczym [Water in agricultural landscape]. Wydawnictwo IMUZ, Falenty, 29-43 [in Polish].

Mapa glebowo-rolnicza, NMT. Retrieved from Mapy.opolskie.pl.

Mapa topograficzna o godle M-33-48-D-a-4 Dobrzeń Wielki. Skala 1:10 000. Układ 1992. Główny Geodeta Kraju.

MARCILONEKS.,KOSTRZEWAS.,NYCK., DRABIŃSKI A. 1995: Cele i zadania współczesnych melioracji wodnych. In: Ekologiczne aspekty melioracji wodnych, L. Tomiałojć (Ed.). Wydawnictwo Instytutu Ochrony Przyrody PAN, Kraków, 71-84.
MIODUSZEWSKI W. 2016: Innowacyjne metody tworzenia małej retencji. [In:] Innowacyjne metody gospodarowania zasobami wody w rolnictwie. Wydawnictwo Centrum Doradztwa Rolniczego w Brwinowie, Brwinów, 11-26 [Engl. summ.].

MIODUSZEWSKI W., ŁOŚ M.J. 2002: Mała retencja $\mathrm{w}$ systemie ochrony przeciwpowodziowej kraju [The small retention in the systems of national flood protection]. Gosp. Wodna 2, 68-73 [Engl. summ.].

MOSIEJ J., PIERZGALSKI E., JEZNACH J. 2011: Współczesne uwarunkowania gospodarowania wodą na obszarach wiejskich [Contemporary issues of water management in rural areas]. Post. Nauk Rol. 63 (1), 25-36 [Engl. summ.].

MROZIK K., PRZYBYŁA Cz. 2013: Mała retencja $\mathrm{w}$ planowaniu przestrzennym [Small retention in spatial planning]. WFOŚiGW, Poznań [in Polish].

NYC K., POKŁADEK R., 2008: Aktualne problemy melioracji użytków zielonych [Current problems of land reclamation in grasslands]. Woda Środ. Obsz. Wiej. 2b (8), 97-103 [Engl. summ.].

NYC K., POKŁADEK R. 2007: Celowość i kierunki rozwoju melioracji w Polsce [Purposefulness and directions of amelioration development in Poland]. Wiad. Melior. Eak. 3, 101-105 [in Polish].

Program Ochrony Środowiska wraz z Planem Gospodarki Odpadami dla Gminy Dobrzeń Wielki na lata 2005-2008 z uwzględnieniem perspektywy na lata 2009-2012 [Environmental Protection Program together with the Waste Management Plan for the Dobrzen Wielki Commune for the years 2005-2008 taking into consideration the perspective for the years 2009-2012]. Tom I. Program Ochrony Środowiska. Zakład Systemów Ekologicznych CMG KOMAG, Gliwice, [in Polish].

PRZYBYŁA Cz., BYKOWSKI J., MROZIK K., NAPIERAŁA M. 2011a: Rola infrastruktury wodno-melioracyjnej $\mathrm{W}$ procesie suburbanizacji [The role of water and drainage system infrastructure in the 
process of suburbanization]. Rocz. Ochr. Środ. 13, 769-786 [Engl. summ.].

PRZYBYŁA Cz., BYKOWSKI J., RUTKOWSKI J. 2011b: Environmental conditions of water courses maintenance in the aspect of application the new generation multi-task machine. J. Res. Appl. Agricul. Eng. 56 (4), 71-78 [Engl. summ.].

RUTKOWSKI J., BYKOWSKI J., PAWŁOWSKI T., PRZYBYŁA Cz., RATAJCZAK P., WOŹNIAK P. 2011: Potrzeby w zakresie konserwacji rowów i kanałów melioracyjnych podstawą koncepcji nowej maszyny [The need for maintenance of drainage ditches and channels based on the concept of a new machine]. Nauka Przyr. Technol. 5 (5), \# 94 [Engl. summ.].

SŁYŚ D. 2008: Retencja i infiltracja wód deszczowych [Retention and infiltration of rainwater]. Wydawnicwo Politechnika Rzeszowska, Rzeszów [in Polish].

SOBOTA J. 2003: Hydraulika i mechanika płynów [Hydraulics and fluid mechanics]. Wydawnictwo Akademi Rolniczej we Wrocławiu, Wrocław [in Polish].

WIATKOWSKI M. 2015: Problemy gospodarki wodnej zbiornika Młyny na rzece Julianpolka [Problems of water management in the reservoir Mlyny located on the Julianpolka river]. Acta Sci. Pol. Formatio Circumiectus 14 (3), 191-203 [Engl. summ.].

WIATKOWSKI M. 2016: Przegląd wybranych problemów gospodarki wodnej na obszarze zlewni rzek [Overviews of some problems with water management in rivers catchment area]. In: Innowacyjne metody gospodarowania zasobami wody $\mathrm{w}$ rolnictwie [Innovative methods of water resources management in agriculture], W. Drobek, J. Kuś, M. Wiatkowski, G. Żurek (Eds). Wydawnictwo Centrum Doradztwa Rolniczego w Brwinowie, Brwinów 27-59 [Engl. summ.].

WIATKOWSKI M., GRUSS Ł. et al. 2012: Inwentaryzacja terenowa urządzeń melioracji podstawowych i szczegółowych na obszarze Gminy Dobrzeń Wielki [Field inventory of basic and detailed drainage systems in the area of the Dobrzen Wielki Commune]. Opole - Dobrzeń Wielki [typescript] [in Polish].

WOS A. 1999: Klimat Polski [The Climate of Poland]. Wydawnictwo Naukowe PWN, Warszawa [in Polish].

Streszczenie: Analiza hydrologiczno-hydrauliczna przepustowości i funkcjonowania matego cieku nizinnego na Nizinie Ślaskiej $w$ aspekcie zagospodarowania wód opadowych. Zabudowane obszary zlewni małych cieków nizinnych, zwłaszcza na odcinkach ujściowych, są szczególnie narażone na działanie niszczących sił natury. Nasilające się ekstremalne zjawiska przyrodnicze, takie jak gwałtowne powodzie i długotrwałe susze, powodują, że budowanie urządzeń melioracyjnych oraz hydrotechnicznych staje się koniecznością. Niniejsza praca prezentuje wyniki kompleksowej analizy hydrologiczno-hydraulicznej przepustowości funkcjonowania małego cieku nizinnego w aspekcie zagospodarowania wód w zlewni tego cieku. Przedstawione studium przypadku jest propozycją do wykorzystania, zarówno przez projektantów, jak i specjalistów z zakresu gospodarki wodnej, metod wyznaczania opadów nawalnych w małych niekontrolowanych zlewniach rolniczych na potrzeby zagospodarowania wód opadowych. Analizowany obszar małego cieku R-4 jest zlokalizowany na terenach użytkowanych rolniczo, w miejscowości Dobrzeń Wielki (województwo opolskie, w dorzeczu górnej Odry). Autorzy zweryfikowali przepustowość istniejącego cieku R-4 według normy europejskiej EN 752:2008 oraz wykonali obliczenia hydrologiczne dla analizowanego terenu oraz obliczenia hydrauliczne cieku dla R-4. Stwierdzono, że mały ciek nizinny oraz zlokalizowane na nim budowle komunikacyjne (przepusty i rurociagi) maja małą przepustowość hydrauliczną. W związku z powyższym przedstawiono koncepcję zagospodarowania wód opadowych odprowadzanych omawianym ciekiem. Zaproponowano wykonanie zbiornika małej retencji o łącznej pojemności $3132 \mathrm{~m}^{3}$ i powierzchni $2088 \mathrm{~m}^{2}$. Do obliczeń dopływu wody do zbiornika zastosowano model Bogdanowicza i Stachego, ponieważ obliczona według tej formuły maksymalna wielkość opa- 
dów deszczu na terenach rolniczych jest dostosowana do wymagań normy EN 752:2008. Dodatkowo stosując tę formułę, uzyskano największe wartości odpływu w porównaniu z pozostałymi modelami. Przeprowadzone badania wpisują się w zadania stawiane obecnie gospodarce wodnej na obszarach wiejskich, gdzie nastapiły zmiany zagospodarowania.
MS received July 2017

Authors' address:

Mirosław Wiatkowski, Łukasz Grusss Instytut Inżynierii Środowiska Uniwersytet Przyrodniczy we Wrocławiu pl. Grunwaldzki 24, 50-363 Wrocław

Poland

e-mail: miroslaw.wiatkowski@upwr.edu.pl lukasz.gruss@upwr.edu.pl 